\title{
REGIONAL DEVELOPMENT POLICY IN INTERNATIONAL CONTEXT
}

\author{
Carmen Liliana CIOBANU, \\ "Tomis" University, Constanţa, \\ 6 Piata Romana, $1^{\text {st }}$ District, Bucharest, 010374, Romania \\ carmenciobanu@ymail.com
}

\begin{abstract}
The European Union regional method is a revolutionary one, with the purpose of expanding and allocating resources for disadvantaged regions. Its progress is monitorized in order to track the efficient use of funds and the application of suitable measures at European level policy interaction as a Member State actions can bring consequences for others. Regional development targets all the subjects that are currently being discussed at national or European level, the effects of the reorganization, the greatest achievement concerning economic and social cohesion, mitigating intra- and inter regional differences.
\end{abstract}

Keywords: Risk, analysis, decisions, funding sources, investments

JEL Classification: G23, G32, L25.

\section{Introduction}

EU's regional development policy (or cohesion policy) is a policy of solidarity at European level and has as its main objective the reduction of economic and social disparities between Member States, targeting important areas such as: encouraging and developing enterprises, attracting investment, transport, agriculture, urban and rural development, education, culture, quality and environmental protection, growth, employment and training. The integration of the Romanian economy into the structures of the European economy, investments, regional disparities, employment, development and economic growth, inequality, poverty represent fundamental problems for the economic science, permanent issues of concern meant to contribute to their functioning mechanisms. 
The concept of "regional development" is relatively new in Central and Eastern Europe, it was born and evolved due to the introduction of the democratic regime and the enhancement of social and economic progress in the sense of increasing territorial integrity and the expansion of advantageous cooperation between countries.

The basic notion on which the doctrine of regional expansion is based is the economic and social unity mirrored in the planning and organization of territories, balanced economic and social development, being the attribute of development that guarantees the harmony between economic efficiency and social justice. From this point of view, it is appreciated that the asymmetric development of the territories and the installation of regional gaps presupposes the economic conjuncture that could become the origin of economic and political lability. The concern for territorial development imbalances dates back to a long time and continues to exist, the study of these gaps being initiated after the Second World War.

Regional development aims to stimulate and diversify economic activities, boost private sector investment, reduce unemployment, improve living standards.

\section{Objectives and principles of regional development policy}

The economic, social and political changes have determined the notion of "regions" - areas above borders, which combine geographic, cultural, social and administrative components, active entities with decision-making power.

The most important features of regionalization are the following: regional identity, temporal dimension and the relational system of the regions (Bakk and Benedek, 2010).

The objectives of regional development policy are as follows:

- reducing existing regional gaps, in particular stimulating balanced development in deprived areas, preventing new gaps;

- fulfillment of the requirements for integration in the structures of the European Union, absorption of the structural and cohesion funds;

- agreeing with governmental development policies, boosting regional cooperation, economic development.

The regional policy of the European Union is an extremely dynamic activity at Community level, viewed at both national and national level, from the perspective of the Member States. 
The legal basis of the Community's regional development policy was established by the Treaty of Rome, according to which the objective of regional policy is "to reduce existing differences between the increasingly development of some regions and the stagnation of less developed regions or islands, including rural areas".

The principles of regional development policies are:

- decentralization of the administration, from the throughoutly national level to the regional one;

- partnership between participants in regional development;

- planning the use of resources in a balanced way;

- co-financing - the financial contribution of beneficiaries of regional development programs and projects.

Starting from the idea that integration of regions is more efficient and more useful than national integration, Romania needs to exploit this opportunity, adjusting its institutional potential, engaging political factors, coordinating decision-making levels and stimulating the contribution and involvement of citizens.

Macroeconomic processes can not solitary the development phenomenon at national level, development in any state being defined by differences in intensity from one region to another, from one city to another.

The notion of "regional development" at present has different connotations across the European Union, so in some countries it is seen as an indication of the economic problems faced by countries lagging behind the most developed and more endowed from the point of view of natural resources, etc.

The emphasis on globalization underlines the importance of regions in economic development, which are perceived as active and causal parts of economic development, areas where the most advanced systems of socioeconomic development and innovation are cluttered.

The notion of regional development derives from the economic development, analyzing the spatial, zonal or local aspects of this development. According to some researchers and analysts, smaller areas development is the capability of city districts to generate and merchandise goods and services, the use of their own resources and attracted resources, and the ability of citizens to earn higher incomes. 
Figure 1. Territorial disparities in EU

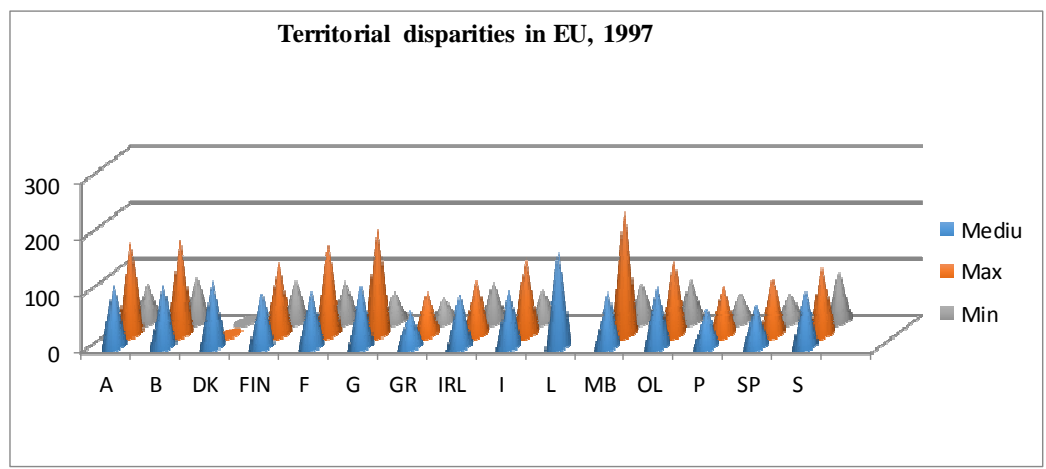

Source: Personal contribution

Regional development gaps characterize the differences between regions as to their potential to provide a chance to earn incomes for its inhabitants.

Treating regional development in other countries implies ensuring effective collaboration among all residents in national, economic, social and political processes. At the same time, there are states that regard this notion as a territorial expansion of regions far away from the most evolved economic nucleus. Consequently, regional development is the science of governance through Community funds.

Table 1. Development imbalances between Member States' regions

\begin{tabular}{|c|c|c|c|c|c|c|c|c|}
\hline \multirow[t]{2}{*}{ State } & \multirow{2}{*}{$\begin{array}{c}\text { Territo } \\
\text { ry } \\
\text { thousa } \\
\text { nd km2 }\end{array}$} & \multirow{2}{*}{$\begin{array}{l}\text { Popul } \\
\text { mln. } \\
\text { loc. }\end{array}$} & \multirow{2}{*}{$\begin{array}{c}\text { No. } \\
\text { Reg } \\
\text { NUTS II }\end{array}$} & \multirow{2}{*}{$\begin{array}{c}\text { Average } \\
\text { area /area } \\
\text { thous km2 }\end{array}$} & \multirow{2}{*}{$\begin{array}{c}\text { Average } \\
\text { area / } \\
\text { area } \\
\text { thous loc }\end{array}$} & \multicolumn{3}{|c|}{$\begin{array}{c}\text { PIB per capita \% to UE, } \\
\text { UE }(15)=100\end{array}$} \\
\hline & & & & & & Mediu & Minim & $\begin{array}{c}\text { Maxi } \\
\mathrm{m}\end{array}$ \\
\hline Bulgaria & 110,9 & 8,5 & 6 & 18,5 & 1417 & 22 & 22 & 24 \\
\hline Cehia & 79 & 10,3 & 8 & 9,9 & 1288 & 60 & 47 & 115 \\
\hline Estonia & 45,2 & 1,5 & $5 *$ & 9,0 & 300 & 37 & 37 & 37 \\
\hline Letonia & 64,5 & 2,5 & 5 & 12,9 & 500 & 31 & 31 & 31 \\
\hline Lituania & 65,2 & 3,7 & $5 *$ & 13,0 & 740 & 28 & 28 & 28 \\
\hline Polonia & 312,6 & 38,7 & 16 & 19,5 & 2419 & 36 & 26 & 53 \\
\hline România & 238,4 & 22,5 & 8 & 29,8 & 2813 & 28 & 22 & 40 \\
\hline Slovenia & 20,3 & 1,9 & 12 & 1,7 & 158 & 69 & 69 & 69 \\
\hline Slovacia & 49 & 5,4 & 4 & 12,3 & 1350 & 49 & 39 & 99 \\
\hline Ungaria & 93 & 10 & 7 & 13,3 & 1429 & 49 & 33 & 72 \\
\hline $\begin{array}{l}\text { Rep } \\
\text { Moldova }\end{array}$ & 33,8 & 3,6 & 12 & 2,82 & 300 & 10 & 6 & 21 \\
\hline
\end{tabular}


At the EU level, the phenomenon of progressive integration along with the development of the political sector through the surrender of the authority from the national to the European level, contributed to the ascendant development of the regional development policy, implemented through financial instruments, based on principles.

The offset principle assumes that the European Regional Development Policy was created with the aim of reimbursing the specific costs and unfavorable situations of EU membership among Member States by making compensations available to lagging regions.

The redistributive principle consists in optimizing the distribution of usable funds from the Member States. Putting a budget for a specific purpose into an amount for the regions lagging behind in a European-level framework is a cost-effective placement for the prospective prosperity of all Member States.

The principle of endogenous growth refers to the support of the circulation of resources, which can determine the technological innovations in the region. The impact of productivity optimization policy leads to increased development capacity at regional level.

The rationale behind the implementation of the above principles is to reduce territorial disparities by supporting poorly developed regions in order to reach a level similar to that of developed regions.

The latest enlargements of the European Union are a real instigation in achieving the objectives of regional policy and the effectiveness of structural instruments by supporting competitiveness, sustainable expansion, economic and social adaption of underdeveloped regions.

At national level, regional development is implemented through specific instruments.

The territorial demarcation of the country's economic sector is an instrument that has diminished its usefulness. Another point of view of this instrument is the social acquisitions made by European countries with a view to the acquisition, especially goods from disadvantaged regions. Since these purchases have been identified as being based on discrimination, they are no longer used at this time.

With the Repositioning of Business Development tool, the state has contributed to discouraging start-ups in overcrowded urban environments and encouraging business development by setting up new businesses in suburbs or disadvantaged areas. 
Business stimulus is being used to encourage organizations to produce and invest in disadvantaged regions by making available preferential credits, tax incentives, subsidies to create and maintain jobs, and so on.

The realization of the infrastructure for the regional development resulted in the establishment of an information infrastructure, scientific research centers, investments in social infrastructure, etc.

Figure 2. The 8 development regions in Romania

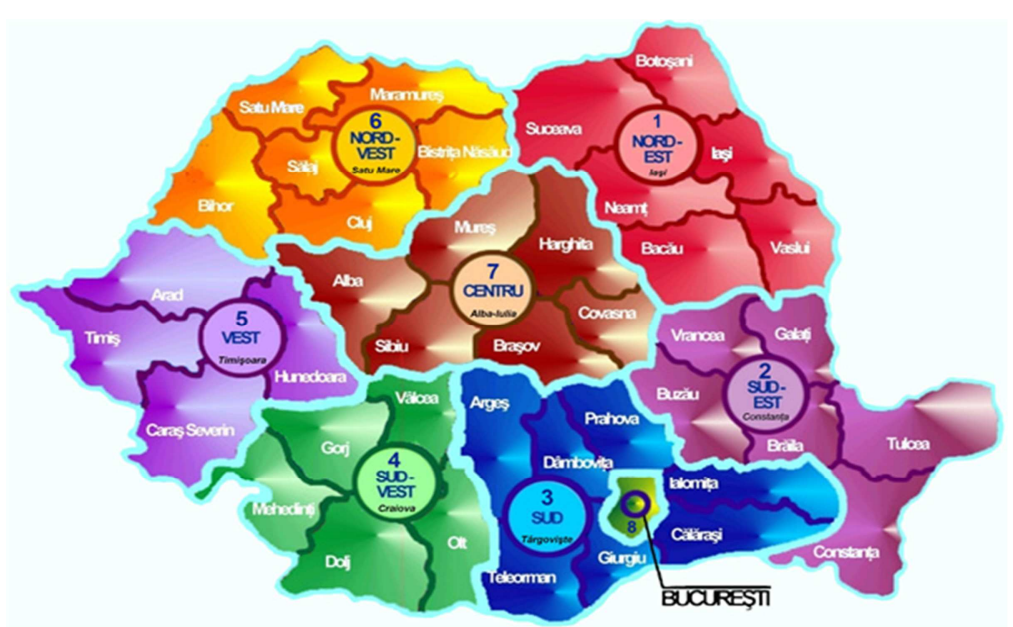

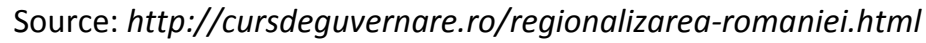

Regional development - is aimed at stimulating and diversifying economic activities, boosting private sector investment, reducing unemployment, improving living standards.

The territory of Romania is divided into eight development regions, each comprising several counties. The 8 development regions in Romania are: North East, South - East, South, South - West, West, North - West, Center, Bucharest Ilfov. In 2008, the region with the highest poverty rate was the North-East region (27.2\%), and the least poor was the Bucharest-llfov region (4.7\%). A high level of poverty is found in the South - West $(23.3 \%)$ and South - East $(22.7 \%)$ regions. In order to promote balanced development in Romania, the following aspects need to be avoided: diminishing values in the regions of the country in relation to Bucharest, the disproportionate development between west and east, north and east; inside regions; small town regression. 


\section{Regional policy instruments - Structural and Cohesion Funds}

The implementation of regional policies is based on the Structural Funds considered to be the most valuable financial instruments with the help of Member States' contributions, relative to their economic strength. The European Commission outlines the main directions for regional policy objectives for each programming phase. Member States shall formulate multi-annual regional development programs that are capable of attracting funding through structural instruments.

The main objective of the European Union is economic and social cohesion, which can be achieved through the Structural Funds. The funds are aimed at meeting the EU's priorities for promoting competitiveness and creating new jobs. For 2014-2020, the European Commission has adopted a draft legislative package that is the framework for EU cohesion policy. The new proposals are designed to strengthen the strategic dimension of policy and ensure that EU investment focuses on Europe's long-term growth and jobs objectives (Europe 2020). There are 23 million unemployed in the European Union and 113 million at or below the poverty line. The EU needs to define the direction it wants to evolve by 2020.

To this end, the Commission proposes the following main objectives for the EU:

- 75\% of the population aged between 20 and 64 should have a job;

- 3\% of EU GDP should be invested in innovation, research and development (C-D);

- "20/20/20" climate change / energy targets should be met (including a $30 \%$ reduction in emissions if favorable conditions are available);

- education - the early school drop-out rate should be reduced below $10 \%$ and at least $40 \%$ of the young generation (30-40 years) should have higher education;

- reducing poverty - the number of people at risk of poverty should be reduced by at least 20 million.

Table 2. Programming $2014-2020$

\begin{tabular}{|l|l|}
\hline European Policy & \multicolumn{1}{c|}{ Operational Program } \\
\hline \multirow{4}{*}{ Cohesion Policy } & Great Infrastructure Operational Program \\
\cline { 2 - 2 } & Human Capital Operational Program \\
\cline { 2 - 2 } & Administrative Capacity Operational Program \\
\cline { 2 - 2 } & Regional Operational Program \\
\hline
\end{tabular}




\begin{tabular}{|c|l|}
\hline \multirow{2}{*}{$\begin{array}{c}\text { European Territorial } \\
\text { Cooperation }\end{array}$} & Competitiveness Operational Program \\
\cline { 2 - 2 } & Technical Support Operational Program \\
\cline { 2 - 2 } & Territorial Cooperation Program Romania - Hungary \\
\hline \multirow{2}{*}{ Common Agricultural Policy } & Rural Development Operational Program \\
\cline { 2 - 2 } & Operational program for fishing \\
\hline
\end{tabular}

Source: Personal contribution

Solutions, proposals and directions for action to achieve the proposed objectives to ensure Romania's social and economic development could be represented by the expertise of some regional development specialists, providing information channels, encouraging cooperation between institutions, universities, administrations public and economic agents, the regular training of people seeking access to European funds, the removal of bureaucracy, facilitating access to information for all actors in the business environment and institutions, and providing an up-to-date database at the development region level for real.

Member States, through their Partnership Contracts agreed with the Commission, will commit themselves to reducing their investment priorities in line with these objectives. This package also harmonises the rules on different funds dedicated to, inter alia, rural development, maritime affairs and fisheries, with a view to increasing the coherence of EU action.

Europe 2020 proposes the following complementary priorities: smart growth implemented through the development of a knowledge and innovation economy, sustainable growth through the promotion of a resource-efficient, greener and more competitive economy and inclusive growth Ensured by promoting an economy with a high employment rate that ensures social and territorial cohesion.

The focus on a limited number of investment priorities in line with these objectives will be the central element of the new Partnership Contracts that Member States will conclude with the European Commission. They will set clear targets and set up a financial performance reserve to reward regions that best meet their goals.

In order to ensure that the impact of EU investment on growth and jobs is not compromised by unviable macroeconomic policies or weak administrative capacity, the Commission may request a review of the programs or may suspend funding unless corrective action is taken.

The impact of the funds will be strengthened by simplifying and harmonizing the rules of the various funds, including those related to rural 
development and maritime affairs and fisheries. A single set of rules will apply to five different funds.

A more integrated approach will also ensure that these different funds respond to coherent objectives and mutually reinforce their effects.

The areas covered by the new strategy are: transport and infrastructure, the environment and climate change, the energy sector, competitiveness and growth, education, employment and social inclusion, tourism, culture / cultural heritage, health and social services, regional development, agriculture, administration, territorial dimension (the role of cities, areas with specific geographical and demographic problems, border areas, macro-regional EU strategies).

\section{Conclusions}

Regional development policy represents all the measures planned by the local and central public authorities, together with private and public economic agents, with the intention of ensuring economic growth, sustainable development, and raising the standard of living. Regionalization represents a solution in reducing development gaps, while ensuring better absorption of European funds, this involves establishing the number, profile, areas and residences of development regions.

Many of the problems identified in Romania in order to attract European funds could be solved through standard procedures developed for all operational programs and a manual of these procedures containing models, reducing bureaucracy, introducing financial corrections imputed to the beneficiary, and Not the project to not waste the European funds attracted by large punishments for the fraudsters, by motivating the staff involved in the implementation of the projects and by employing qualified staff with experience in the implementation of projects funded by European funds.

The role of the state is decisive in terms of creating opportunities for all regions to grow, increasing the attractiveness of regions and reducing gaps with compensation policies (infrastructure, environmental protection, research, development and innovation, service improvement, redistribution Income and support for local projects).

The European funds are a very important element regarding the economic development of the Romanian regions. Authorities will have to study the unfavorable component of economic growth, namely increasing gaps. 
The elaboration of regional policies in Romania and their changes must be done with great care and responsibility by the administrative authorities and the governors.

\section{References}

Baciu Livia (2013) "Eficacitate vs. eficiență. O analiză conceptuală a justificării intervenției statului în economie", Editura Academiei Române, București Miklos Bakk, Jozsef Benedek (2010). "Politicile regionale în România", Editura Polirom, Bucureşti Ionescu Romeo (2008) „Dezvoltare regională”, Editura didactică şi pedagogică, Bucureşti Popescu Gh. H. (2007). „Economie europeană”, Editura Economică, Bucureşti

Victor Boştineanu (2013) „Ultimii paşi - Absorbţia Fondurilor Structurale şi de Coeziune 20072013" 